\title{
Akçaağaç Şurubu Hastalığının Beslenme Tedavisinde Güncel Yaklaşımlar
}

\author{
Elif Maden ${ }^{1 *}$, Sümeyye Uçak ${ }^{2}$, Yasemin Y1lmazer ${ }^{3}$ \\ 1* İstanbul Sabahattin Zaim Üniversitesi, Sağlık Bilimleri Fakültesi, Beslenme ve Diyetetik Bölümü, İstanbul, Türkiye (ORCID: 0000-0001-8697-7469) \\ dytelifmaden@gmail.com \\ 2 İstanbul Sabahattin Zaim Üniversitesi, Sağlık Bilimleri Fakültesi, Beslenme ve Diyetetik Bölümü, İstanbul, Türkiye (ORCID: 0000-0003-1563-8464) \\ dyt.sumeyyeucak@gmail.com \\ 3 İstanbul Sabahattin Zaim Üniversitesi, Mühendislik ve Doğa Bilimleri Fakültesi, Moleküler Biyoloji ve Genetik Bölümü, İstanbul, Türkiye (ORCID: 0000-0003- \\ 2190-073X) yasemin.yilmazer@izu.edu.tr
}

(İlk Geliş Tarihi 21 Ocak 2021 ve Kabul Tarihi 10 Mayıs 2021)

(DOI: 10.31590 /ejosat.866160)

\begin{abstract}
ATIF/REFERENCE: Maden, E., Uçak, S., Yılmazer, Y. (2021). Akçaağaç Şurubu Hastalığının Beslenme Tedavisinde Güncel Yaklaşımlar. European Journal of Science and Technology, (25), 145-151.
\end{abstract}

\section{$\ddot{O} \mathbf{z}$}

Akçaağaç Şurubu İdrar Hastalığı (Maple Syrup Urinary Disease; MSUD) lösin, izolösin ve valin metabolizmasındaki bozukluk sonucu oluşan, idrarda akçaağaç şurubu kokusu ile karakterize otozomal resesif geçişli bir hastalıktır. Bu hastalığın Türkiye'de görülme sıklığı 1/200.000'dir. MSUD hastaları tarafından sunulan başlıca klinik özellikler arasında ketoasidoz, büyüme gelişme geriliği, yetersiz beslenme, apne, ataksi, nöbetler, koma, psikomotor gecikme, hiperaktivite ve zihinsel gerilik görülmektedir. Akçaağaç şurubu idrar hastalığının klasik, aralıklı, orta düzey, tiamine duyarlı, E3 eksikliğine bağlı olmak üzere beş tipi bulunmaktadır. Yaygın olarak yenidoğanlarda görülen klasik MSUD, yetersiz beslenmeden kaynaklı olarak komayla ve tedavi edilmezse ölümle sonuçlanabilir. Semptomların görülmeye başlaması, protein alım miktarına bağlı olarak değişebilir. Semptomların başlamasından sonraki birkaç gün içinde tedavi edilen hastaların çoğu hayatta kalır ve herhangi bir nörolojik hasar geliştirmeyebilir. Akut kriz ataklarının düzeltilmesinden sonra Dallı Zincirli Amino Asit'leri (DZAA) kısıtlamaya yönelik uzun süreli beslenme tedavisine geçilir ve bu tedavinin yaşam boyu sürdürülmesi gerekmektedir. Son yıllarda yapılan araştırmalar, beslenme tedavisine erken başlanılması halinde oluşabilecek beyin hasarlarının en aza indirgendiği gösterilmiştir. Bu derlemede akçaağaç şurubu idrar hastalığı bulunan bireylerde beslenme tedavisinin öneminin vurgulanması amaçlanmıştır.

Anahtar Kelimeler: MSUD, Lösin, İzolösin, Valin, Dallı Zincirli Aminoasit, Beslenme Tedavisi.

\section{Current Approaches in the Treatment of Maple Syrup Urinary Disease}

\begin{abstract}
Maple Syrup Urinary Disease (MSUD), an autosomal recessive inherited disease, occurs as a result of defects in leucine, isoleucine and valine metabolism and is characterized by the odor of maple syrup in the urine. The incident of this disease is $1 / 200,000$ in Turkey. The main clinical features presented by MSUD patients are ketoacidosis, growth and development retardation, malnutrition, apnea, ataxia, seizures, coma, psychomotor delay, hyperactivity and mental retardation. MSUD has five types as classical neonatal, intermittent, intermediate, sensitive to thiamin and connected to deficiency E3. Commonly seen the neonatal MSUD in newborns can result in coma as a resuts of malnutrition. It can result in death if left untreated. The onset of symptoms may vary depending on the amount of protein in the diet of patients. Most patients treated within a few days of the onset of symptoms survive and may not develop any neurological damage. After the correction of acute crisis attacks, long-term nutritional therapy is started to restrict Branched Chain Amino Acid. Such treatment must be continued for life time. Recent studies have shown that brain damage may minimize if the nutritional therapy is initiated earlier. In this review, it is aimed to emphasize the importance of nutritional therapy in individuals with MSUD.
\end{abstract}

Keywords: MSUD, Leucine, Isoleucine, Valine, Branched Chain Amino Acid, Nutritional Treatment.

\footnotetext{
* Sorumlu Yazar: İstanbul Sabahattin Zaim Üniversitesi, Sağlık Bilimleri Fakültesi, Beslenme ve Diyetetik Bölümü, İstanbul, Türkiye, ORCID: 0000-0001-8697-7469, dytelifmaden@gmail.com
} 


\section{Giriş}

Besinlerin yapı taşını oluşturan yağlar, proteinler, aminoasitler, vitamin ve diğer farklı yapıların miktar ve çeşitlerine göre çeşitli reaksiyonlara sebep oldukları düşünülmektedir (Köseoğlu, 2020). Hücrelerin yapısını birçok farklı tipte protein bulunmaktadır (Altuntaş ve ark., 2020). Proteinler amino asitlerden oluşur ve yaşam için elzemdir (Köseoğlu, 2019).

Akçaağaç Şurubu Hastalığı (MSUD); valin, lösin ve izolösin dekarboksilasyonunda rol oynayan Dallı Zincirli Alfa- Ketoasit Dehidrogenaz (BCKAD) enzimindeki hasarlar sonucunda oluşmuş, doğuştan gelen bir metabolizma hastalığıdır. Valin, lösin, izolösin ve toksik metabolitlerinin kan ve idrarda birikmesi ile karakterize olup idrarda akçaağaç şurubu kokusu gözlemlenir (Köksal \& Gökmen, 2019; Blackburn ve ark., 2017). Otozomal resesif geçişli metabolik bir hastalık olan MSUD'nin görülme sıklığı dünya genelinde 1:185.000 canlı doğum olduğu bildirilmiş olsa da bu oranın daha yüksek olabileceği tahmin edilmektedir (Karahan ve ark., 2014). ABD'de Mennonitesler'de görülme sıklığ 1 1/176, Gürcistan'da 1/84.000, İspanya'da 1/50.000 ve ülkemizde ise bu oran 1/200.000'dir.

MSUD patogenezinde genetik faktör olarak E1 - alfa subunit gen (BCKDHA), E1-beta subunit gen (BCKDHB) ve E2 subunit gen (DBT) olmak üzere üç gen sorumlu tutulmaktadır. Bu genlerin allellerinde oluşan patojenik varyantların işlev kaybına neden olmasıyla hastalık ortaya çıkar (Demir Köse ve ark., 2016). MSUD de Alfa-Ketoasit Dehidrojenaz Kompleksi (BCKD)'nin dört alt birim bileşeni vardır. Bu bileşenler; E1a, E1b, E2 ve E3'tür. Her allelin alt birimini kodlayan patojenik varyantlar enzim kompleksinin aktivitesinin azalmasina ve DZAA'lerin dokularda ve plazmada karşılık gelen BCKA'in birikmesine neden olabilmektedir.

Tablo 1. BCKD’nin Alt Bileşenleri

\begin{tabular}{|l|l}
\hline MSUD tip 1A & BCKA dekarboksilaz (E1) alfa alt birimi \\
\hline MSUD tip 1B & BCKA dekarboksilaz (E1) beta alt birimini \\
\hline MSUD tip 1B & Dihidrolipoil transasilaz (E2) alt birimini \\
\hline
\end{tabular}

\section{MSUD'nin Patofizyolojisi}

Lösin, LAT1 (SLC7A5) aminoasit taşıyıcısı yoluyla beyne girmek için diğer dokuz amino asitle rekabete girer ve beyin kimyasını değiştirerek katabolik durumlar sırasında hızla artabilir. Dallı zincirli amino asit transaminaz (BCAT1), lösin ve aketoglutarattan (aKG'den) a-ketoizokaproik asit (aKIC) oluşumunu katalize eder; aKIC beyine monokarboksilat taşıyıcısı (SLC16A1) taşıyıcıs1 yoluyla girmekte olup yüksek konsantrasyonlarda nörotoksiktir (Kevin ve ark., 2020). Dokularda artmış miktarda bulunan aKIC, BCAT1 ile normal akışı tersine çevirmektedir ve böylece glutamat dokularını tüketir. Klasik MSUD'lu kişilerde, gerçekleşen bu karşılıklı dönüşümler lösin ile glutamat, glutamin ile alanin arasındaki ters ilişkileri göstermektedir. Tahminen metabolik ensefalopati sırasında ve beyin dokusunda gözlenen laktat yükselmesinin altındaki sebep de bu dönüşümden kaynaklanmaktadır (Kevin ve ark., 2020).
Resim 1. MSUD'nin Patofizyolojisi

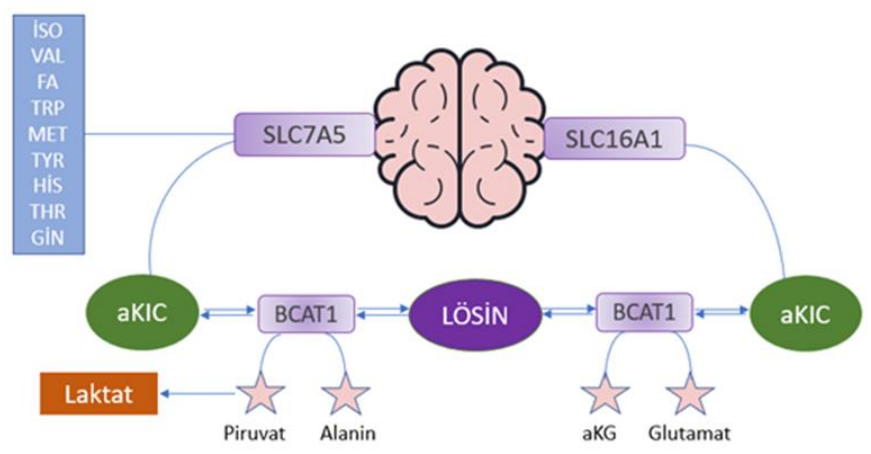

\section{Risk Faktörleri}

Kalıtsal metabolik hastalıkların prenatal tanısı, özellikle akraba evliliği daha yüksek görülen ülkelerde önemlidir (Chapman, 2014). Türkiye Nüfus ve Sağlık araştırmaları verilerine göre Türkiye'de akraba evliliği oranı \%22- \%24 olduğu tespit edilmiştir (Koc \& Eryurt, 2017). Akraba evliliğinin fazla görülmesinden dolayı kalıtsal metabolizma hastalıklarının ülkemiz için önemli bir sağlık sorunudur (Tanacan ve ark., 2019).

MSUD' de otozomal resesif olan kalitsal hastalıktır ve bu hastalıktan etkilenen bir bireyin her bir kardeşinin etkilenme şansı $\% 25$, etkilenmeme şansı $\% 50$ ve taşıyıcı olma şansı ise $\% 25^{\prime}$ tir. MSUD olan bir aile üyesinde patojenik varyantlar tanımlanmışsa, risk altındaki akrabalar için taşıyıcı testi ve yüksek risk altındaki gebelikler için prenatal tanı yapılması mümkündür (Strauss ve ark., 2020).

\section{Belirti ve Bulgular}

MSUD hastaları tarafından sunulan başlıca klinik özellikler arasında ketoasidoz, büyüme ve gelişme geriliği, yetersiz beslenme, apne, ataksi, nöbetler, koma, psikomotor gecikme, hiperaktivite ve zihinsel gerilik görülmektedir (Muelly ve ark., 2013). MSUD'si olan 17 yetişkin (ortalama 27,5 yaş) üzerinde yapılan çalışmada 12 'sinde $(\% 70,6)$ klinik muayenede bir hareket bozukluğu (esas olarak titreme, distoni veya her ikisinin bir kombinasyonu) bildirilmiştir (Carecchio ve ark., 2011). Ayrıca çalışmalar MSUD nöropatolojisinde oksidatif stresin rol oynayabileceğini göstermiştir (Mescka ve ark., 2014). Lösin, izolösin ve valinin anormal birikimi, beslenme sorunları, kusma, uyuşukluk, sinirlilik ve idrarın karakteristik akçaağaç şurubu kokusu gibi çeşitli semptomlarla sonuçlanır. Dallı Zincirli AlfaKetoasitler (DZAA'ler) dan özellikle lösin beyin hücrelerine sitotoksiktir ve miyelinli beyaz maddeyi etkileyen sitotoksik beyin ödeminde neden olur. Artmış plazma izolösin ise idrarda karakteristik akçaağaç şurubu kokusu ile ilişkilidir. Alfaketoizokaproik asit ve diğer BCKA'lar, kas ve beyindeki transaminasyon reaksiyonlarına müdahale ederek toksisite gösterebilir.

Gerçekleştirilen bir olgu çalışmasında MSUD'li bebekler 5 günlük iken letarji, emme güçlüğü ve idrarında yanmış şeker kokusu gibi semptomlar tespit edilmiştir (Kale \& Karaoğlu, 2017). Semptomların görülmeye başlaması, beslenmelerindeki protein miktarına bağlı olarak değişebilir. Semptomların başlamasından sonraki birkaç gün içinde tedavi edilen hastaların çoğu hayatta kalır ve herhangi bir nörolojik hasar geliştirmeyebilir (Kathait ve ark., 2018). 


\section{MSUD'nin Tipleri}

MSUD klinik bulgular ve tiamine yanıt vermesi bakımından 5 ayrı tipe ayrılır.

\subsection{Klasik (Neonatal) MSUD}

Klasik MSUD en yaygın ve en şiddetli formdur. Bebekler doğduklarında genelde normaldir ama genellikle birkaç gün sağlıklı kalırlar. Doğduktan sonra 12-24 saat içerisinde dallı zincirli amino asitlerin (DZAA'ler; lösin, izolösin ve valin) ve alloizolösin konsantrasyonları artar ve idrarda akçaağaç şurubu kokusu tespit edilebilir. 2 ile 3 gün içerisinde metabolik zehirlenme belirtilerine ve idrarda dallı zincirli alfa-ketoasitler, asetoasetat ve beta-hidroksibutirat varlığı eşlik eder. 4 ile 6 gün içerisinde ensefalopati kötüleşir, akçaağaç şurubu kokusunun idrarda belirgin hale gelir. 7 ila 10 gün içerisinde ciddi serebral ödem, koma ve merkezi solunum yetmezliğinde şiddetli zehirlenme ortaya çıkar (Blackburn ve ark., 2017).

Klasik MSUD'ye sahip bireyler üzerinde yapılan bir çalışmada duygusal hastalık (depresyon, anksiyete ve panik bozukluğu) olasılığ $\% 83$ ile \%100 arasında bulunmuştur (Muelly ve ark., 2013). Yapılan bir başka çalışmaya göre 1964-2013 yılları arasında tedavi edilen yenidoğan MSUD'li hastalarda dışsallaştırma ve anksiyete bozukluluğu yaygın olarak görülüp \%56'sında psikolojik ve psikiyatrik bakıma ihtiyaç duyduğu gözlemlenmiştir (Abi-Wardé ve ark., 2017).

\subsection{Aralıklı (İntermittent) MSUD}

MSUD'nin diğer tipleri Klasik MSUD'den daha hafiftir. Bunlardan ilki ve Klasik MSUD'den sonra en sık görülen aralıklı dallı zincirli ketoasidüridir. Bu tipe sahip bireyler, enfeksiyon veya ameliyat gibi olayların varlığı dışında hiçbir problem yaşamayabilir. Ancak bu rahatsızlık bazı zamanlarda ölümcül olabilmektedir (Nyhan WL ve ark., 2005). Yıllar boyunca hiçbir semptoma rastlamamış hastalarda, hafif bir enfeksiyonla beraber koma, konvülsiyonlar ve ölüm gelişebilir. (Goedde HW ve ark., 1967). Aralıklı MSUD'de yaygın görülen klinik bulgular arasında; normal erken büyüme ve gelişme ve ile beraber şiddetli olabilen epizodik dekompansasyonlar görülebilir (Blackburn ve ark., 2017).

İntermittent MSUD'de biyokimyasal bulgular klasik profile benzer ve DZAA'ler normaldir. Normal BCKD aktivitesi ise \%5$\% 20$ oranındadır.

\subsection{Orta Düzey (İntermediate) MSUD}

Üçüncü form olan İntermediate MSUD' de hastalar genellikle zekâ geriliği ile başvurmaktadır ve diğer iki forma göre daha az rastlanır. Bu tipte görülen belirti ve bulgular arasında; akçaağaç şurubu kulak kiri kokusu, yetersiz beslenme, büyüme yetersizliği, gelişimsel gecikmeler, sinirlilik ve hastalık sırasında ensefalopati bulunmaktadır. İntermediate MSUD'de ise biyokimyasal parametreler klasik fenotipe benzer şekilde görülür ama kantitatif olarak daha az şiddetlidir ve BCKD aktivitesi \%3- \%30'dir (Strauss et al., 2020).

\subsection{Tiamine Duyarlı MSUD}

Tiamine duyarlı MSUD veya diğer adıyla tiamine duyarlı dallı zincirli oksoasidüri, başlangıçta günde $10 \mathrm{mg}$ kadar az tiamine yanıt veren nispeten hafif klinik bulgulara sahip bir hastada tanımlanmıştır (Scriver CR ve ark., 1971). Bu tip hastalarda tiamin takviyesinin iyileştirdiği görülmektedir. Normal BCKD aktivitesi \%2- \%40 'tır ve tiamin tedavisi ile lösin toleransının ve biyokimyasal profilin iyileştirilmesi hedeflenir (Strauss et al., 2020).

\subsection{E3 Eksikliğine Bağlı MSUD}

Nadir görülen bir tiptir ve E3 Eksikliğine bağlı oluşur. E3 eksikliğine bağlı MSUD hastalığı görülen bir olguda ilk hafta beslenme güçlükleri, kusma ve büyüme ve gelişme geriliği şikayetleri ile başvurmuştur (Nyhan WL ve ark., 2005).

\section{Diyetsel Yaklaşım}

Beslenme tedavisi, MSUD'da metabolik homeostazın yenilenmesinde ve sürdürülmesinde önemli bir rol oynar (Frazier ve ark., 2014). Beslenme yönetimi, dallı zincirli amino asitler, lösin kısıtlaması, valin ve izolösin içermeyen besinlerin tüketilmesi ve yeterli enerji, protein, vitamin ve minerallerin sağlanmasını içerir (Calcar, 1980).

\section{MSUD'nin tedavisi 2 aşamada gerçekleşir;}

\subsection{Akut kriz ataklarının tedavisi}

Hastalık sırasında öncelikle katabolizmayı önlemek veya tersine çevirmek için gerekli beslenme yönetimi sağlanmalı ve anabolizma teşvik edilmelidir (Frazier ve ark., 2014). Akut dönemde gerçekleştirilen tedavide metabolik homeostazın düzeltilmesi için DZAA'ler ile birlikte metabolitlerinin de dokulardan ve vücut sıvılarından uzaklaştırılması amaçlanır. Hastalık sırasında DZAA, asit-baz dengesi, idrar $\alpha$-ketoasitler, kan glikozu ve klinik semptomları yakından izlenir. Plazma DZAA düzeylerini düşürmek ve toksik metabolitleri ortadan kaldırmak için diyaliz için en iyi yöntem olan periton diyalizi hemen kullanılır. Diyaliz sonrasında 24 saat içinde plazma valin, lösin ve izolösin düzeylerinde belirgin bir düşme gerçekleşir (Köksal \& Gökmen, 2008; Frazier ve ark., 2014). Plazma lösin değeri yeterli düzeylere indiğinde periton diyalizi kesilir. (Aktuğlu, 2004). Hemofiltrasyon veya diyaliz varlığında, kan gazı, hematokrit, toplam protein, sodyum, kalsiyum, fosfor, üre ve kreatin düzeyleri detaylıca takip edilmelidir (Frazier ve ark., 2014).

MSUD'li hastalarda katobolik durumu düzeltmek için oral veya intravenöz yolla uygulanan beslenme tedavisinde Önerilen Günlük Alım Miktarı'nın (Recommended Daily Allowance; RDA) üzerinde protein, enerji, mineral (özellikle çinko) ve vitamin alımı sağlanmalıdır. Enerji gereksinmeleri büyüme hızına göre değişiklik gösterse de MSUD'li hastaya en az 120-150 $\mathrm{kkal} / \mathrm{kg}$ enerji verilmelidir. Besinlerle karşılanamayan enerji açığı, enerji içeriği yüksek mamalar (fantomalt, polycose vb) ile karşılanmalıdır. Ayrıca hastanın bol sıvı alması da önemlidir (Samour \& King, 2016).

Akut tedavisine başlandığında bir DZAA içermeyen amino asit kaynağına ihtiyaç duyulur. Bir MSUD hastasının tıbbi beslenme tedavisinde DZAA içermeyen parenteral solüsyonlar mevcuttur, gastrointestinal uygulama tolere edilmezse nazogastrik yolla beslenme sağlanabilir (Calcar, 1980).

\subsection{Uzun süreli Beslenme tedavisi}

Akut kriz ataklarının düzeltilmesinden sonra DZAA'leri kısıtlamaya yönelik uzun süreli beslenme tedavisine geçilir ve bu tedavinin yaşam boyu sürdürülmesi gerekmektedir. Beslenme tedavisine erken başlanması oluşabilecek beyin hasarlarını en aza indirgemeyi sağlar (Köksal \& Gökmen, 2019). MSUD'li bireylerin diyetlerinde DZAA kısitlanmasının amacı, DZAA eksikliklerini kontrol altında tutarken mümkün olduğunca 
normale yakın plazma DZAA konsantrasyonları elde etmek ve korumaktır (Strauss ve ark., 2003; Strauss ve ark., 2010). Yüksek Lösin konsantrasyonları çoğunlukla anormal beyin morfolojisi ve bilişsel bozukluk ile ilişkilidir (Hoffmann ve ark., 2006). Bu sebeple olumlu bilişsel sonuçlara ulaşmak için bebekler ve 5 yaşından küçük çocuklar için 75 ile $200 \mu \mathrm{mol} / \mathrm{L}$ arasında ve 5 yaşından büyük bireyler için 75 ile $300 \mu \mathrm{mol} / \mathrm{L}$ arasında sık izleme ile plazma Lösin konsantrasyonlarını korunması tedavide önem teşkil eder. Aynı zamanada metabolik instabiliteyi ve DZAA eksikliklerini önlemek için tüm bireylerde sık izlem ile plazma İzolösin ve Valin konsantrasyonlarını 200 ila $400 \mu \mathrm{mol} / \mathrm{L}$ arasında tutulmalıdır. Büyüme geriliği DZAA'lerin uzun süreli eksikliğinin bir sonucudur (Strauss ve ark., 2003). Bu sebeple DZAA yetersizliğinin önlenmesi için diyete önerilen miktarlarda eklenmelidir. Cilt lezyonlarına bağlı olarak deride pullanma ve soyulmayı önlemek için izolösin 4. günde veya daha öncesinde eklenmelidir (Samour \& King, 2016).

Raporlarda, hedeflenen ve normal referans aralıklarında farklılıklar vardır. Ancak diyet müdahalesinin etkinliğini değerlendirmek, eksiklikleri veya aşırılıkları tespit etmek için sık biyokimyasal izlemenin gerekli olduğu bildirilmiştir. $\mathrm{Bu}$ aminoasitler dokularda sentez edilemediklerinden dolayı diyette az miktarda bulunması gerekir. (Köksal \& Gökmen, 2019).

Tablo 2. MSUD'li Kişilerde Beslenme Tedavisi ile Hedeflenen Lösin, İzolösin ve Valin Değerleri (Köksal \& Gökmen, 2008)

\begin{tabular}{c|c|c}
\hline AMINOASIT & $\begin{array}{c}\text { Hedeflenen } \\
\mathbf{m o l} / \mathbf{L}\end{array}$ & $\begin{array}{c}\text { Normal } \\
\text { Referans Aralı̆̆ } \\
\mathbf{m o l} / \mathbf{L}\end{array}$ \\
\hline LÖSIN & $200-700$ & $65-220$ \\
\hline İOLÖSIN & $100-400$ & $26-100$ \\
\hline VALİN & $100-400$ & $90-300$ \\
\hline
\end{tabular}

MSUD'li bireylerin günlük protein gereksinmesi DZAA içermeyen özel aminoasit karışımları ile sağlanmalıdır. Bu karışımlar;
- $\quad$ MSUD 1- Mix (0-6 ay)

- MSUD 1 (6 ay-2 yaş)

- $\quad$ MSUD 2 (2 yaş ve sonrası)

$\mathrm{Bu}$ tür özel karışımlar doğal besinlerle karıştırılarak uygulanmalı ve uzun süreli açlık durumlarından kaçınılmalıdır. Bebeklerin öğün sayısı günde 8-10 kere, çocukların ise 6-8 kere olmalıdır (Köksal \& Gökmen, 2019). 79 hastayı inceleyen 20 yıllık bir çalışmada, dallı zincirli amino asitlerle rekabet eden yedi amino asidin (Tirozin, Triptofan Histamin, Metiyonin, Treonin, Glutamin, Fenilalanin) taşınmasını düzenlemek için bir çalışma formülü tasarlanmıştır. Formül, LAT1 amino asit substratları, glutamin, alanin, çinko, selenyum ve alfa-linolenik asit ile zenginleştirilmiştir. Bebekler, doğum ile 34 ay arasında çalışma formülü ile başlatılmıştır. Tüm çocuklar 14-33 aylık bir sürede normal olarak büyüme ve gelişme göstermiştir. Çalışma formülünün klasik MSUD tedavisinde güvenli ve etkili olduğu sonucuna varılmıştır. Diyetle zenginleştirme, nörotransmitter sentezi ve metil grubu transferi için kullanılan amino asitlerin eksikliğine karşı koruduğu sonucuna varılmıştır (Strauss ve ark., 2010).

MSUD'nin 5 klinik fenotipi bulunduğundan DZAA miktari; yaşa, cinsiyete, sağlık durumuna, genotipe ve protein alımına göre değişiklik gösterir. Intermediate veya intermittent tip MSUD hastaları, klasik MSUD hastalarına göre daha az diyet sınırlamasına gerek duymaktadır. Bununla beraber bu hastalara verilecek DZAA içermeyen aminoasit karışımlarının sürekli günlük olarak ve özellikle ateşli hastalık esnasında kullanılması, asidozisin önlenmesinde fayda sağlar. Ağır tip olan Klasik MSUD'li hastaların ciddi hastalık gelişimin önlemek için beslenme tedavisine hastalıktan ilk şüphelenildiği zaman başlanmalı ve ilk 3 gün DZAA içermeyen aminoasit karışımı verilmelidir (Samour \& King, 2016).

İntermitant ve hafif MSUD tanısı konulmuş çocukların bazılarında 3 hafta yüksek doz tiamin tedavisiyle $(200 \mathrm{mg} / \mathrm{gün})$ klinik ve biyokimyasal bulgularda belirgin düzelme görülürken tiamine yanıtlı MSUD'li çocuklarda idame tedavisinde tiamin desteği yanında diyet tedavisi de uygulanmalıdır (Kara, 2012).

Tablo 3. MSUD İçin Önerilen DZAA’ler, Protein, Enerji ve Sıvı Miktarları (Frazier ve ark., 2014)

\begin{tabular}{|c|c|c|c|c|c|c|}
\hline Yaş & $\begin{array}{c}\text { Lösin } \\
\text { mg / kg }\end{array}$ & $\begin{array}{c}\text { İzolösin } \\
\text { mg / kg }\end{array}$ & $\begin{array}{c}\text { Valin } \\
\text { mg / kg }\end{array}$ & $\begin{array}{c}\text { Protein } \\
\text { g / kg }\end{array}$ & $\begin{array}{c}\text { Enerji } \\
\text { kcal / kg }\end{array}$ & $\begin{array}{c}\text { Sivı } \\
\text { mL / kg }\end{array}$ \\
\hline $0-6$ ay & $40-100$ & $30-90$ & $40-95$ & $2,5-3,5$ & $95-145$ & $125-160$ \\
\hline 7- 12 ay & $40-75$ & $30-70$ & $30-80$ & $2,5-3,0$ & $80-135$ & $125-145$ \\
\hline $1-3$ y1l & $40-70$ & $20-70$ & $30-70$ & $1,5-2,5$ & $80-130$ & $115-135$ \\
\hline 4-8 yaş & $35-65$ & $20-30$ & $30-50$ & $1,3-2,0$ & $50-120$ & $90-115$ \\
\hline $9-13$ yaş & $30-60$ & $20-30$ & $25-40$ & $1,2-1,8$ & $40-90$ & $70-90$ \\
\hline $14-18$ yaş & $15-50$ & $10-30$ & $15-30$ & $1,2-1,8$ & $35-70$ & $40-60$ \\
\hline $\begin{array}{c}19 \text { yaş ve } \\
\text { üzeri }\end{array}$ & $15-50$ & $10-30$ & $15-30$ & $1,1-1,7$ & $35-45$ & $40-50$ \\
\hline
\end{tabular}


Yüksek lösin konsantrasyonları çoğunlukla anormal beyin morfolojisi ve bilişsel bozukluk ile ilişkilidir. Bu yüzden özellikle plazma lösin düzeyleri en alt düzeyde tutulmaya çalışılmalı ve aynı zamanda beslenme ile verilmesi gereken temel aminoasit lösin olmalıdır. MSUD hastası olan çocukların bağışıklık mekanizmaları zayıf olduğu için enfeksiyona yakalanmaları kolaydır. $\mathrm{Bu}$ dönemlerde çocuklarda lösin gereksinmeleri değişebilmektedir (Köksal \& Gökmen, 2019). Verilen lösin düzeylerine göre de valin ve izolösin değerleri hesaplanmalı, beslenme ile tamamlanamayan, eksik kalmış valin ve izolösin dışarıdan toz aminoasit olarak verilmelidir (Köksal \& Gökmen, 2008). Plazma valin ve izolösin seviyeleri lösine göre daha hızlı normale dönerler. Eksiklerinde oluşan bulgularının ortaya çıkmaması için valin ve izolösin normal sınırlar içine girdiklerinde diyete eklenir (Aktuğlu, 2004). 8-10 gün içerisinde plazma lösin düzeyi normal seviyelere gelmeye başladıktan sonra, DZAA'ler doğal protein kaynaklarından özellikle tahıl ürünleri, meyveler ve sebzelerden sağlanmalıdır (Köksal \& Gökmen, 2019). Lösin içermeyen formülle beslenen 15 MSUD hastası incelenmiştir. Lösin kısıtlamasıyla hastaların plazma lösin konsantrasyonları her 24 saatlik periyotta başlangıç değerinin $\% 50$ 'si ile orantılı olarak düşmüştür. $\mathrm{Bu}$ araştırmayla MSUD hastalarının beslenme desteği ve lösin içermeyen formülle lösin seviyelerini tahmin etmeye yardımcı olması amaçlanmıştır (Scott ve ark., 2017).

\section{Uygulanan Farklı Tedaviler}

MSUD tedavisi için incelenen çalışmalar vardır. Bunlar arasında, norlösin, hepatosit nakli, antioksidan takviyesi, sodyum fenilbutirat ve karnitin kullanımı yer alır. Bu önerilerin nasıl etkileyeceğini gösteren sınırlı veri bulunmaktadır (Frazier ve ark., 2014). MSUD hastalarının nörolojik disfonksiyon ve bilişsel bozukluluğun incelenmesi amacıyla genç siçanlarda gözlem yapılmıştır. Kronik DZAA uygulamasından sonra antioksidan olan N-asetil sistein (NAC) ve deferoksaminin (DFx) davranış parametreleri üzerinde inceleme gerçekleştirilmiştir. Tüm sonuçların birlikte ele alınmasıyla motor aktivite değişikliklerinin DZAA uygulamasından sonra hafıza bozukluğuna katkıda bulunmadığını, NAC ve DFx etkilerinin ise DZAA uygulamasından sonra oksidatif beyin hasarından kaynaklanabileceği gösterilmiştir (Scaini ve ark., 2012).

Nöropsikiyatrik sorunların prevalansını bildirmek ve altta yatan mekanizmaları anlamak amaciyla 37 klasik MSUD hastası (5-35 yaş, 26 diyet terapisi, 11 karaciğer nakli sonrası) incelenmiştir. Uyumlu kontrolle karşılaştırıldığında MSUD hastaları biliş, dikkat ve ruh hali bozuklukları açısından daha yüksek risk altında bulunmuştur. Kantitatif proton manyetik rezonans spektroskopisinin kullanılmasıyla MSUD hastalarında spesifik nöropsikiyatrik sonuçlarla ilişkili daha düşük beyin glutamat, N-asetilaspartat (NAA) ve kreatin konsantrasyonları bulunmuştur. Nöropsikiyatrik morbidite ve nörokimya, karaciğer nakledilen ve nakledilmeyen MSUD hastalarında benzer olduğunu bulmuşlardır. Sonuç olarak, amino asit düzensizliğinin nakilden sonra devam eden ve nöropsikiyatrik morbiditelerle ilişkili olduğunu tespit etmişlerdir. (Muelly ve ark., 2012).

Son yıllarda yapılan çalışmalar, hücresel enerji metabolizmasında merkezi işlev oynayan ve MSUD hastalarında eksikliği görülen L-Karnitinin antioksidan rolünü göstermiştir.

L-Kar'in DNA hasarını koruyucu etkisine bakılmak için bir çalışma gerçekleştirilmiştir. Bu çalışmada deney grubuna L-Kar verilirken kontrol grubuna plasebo verilerek Lösin ve aketoizokaproik asit'in (aKIC'nin) periferik tam kan lökositlerinde DNA hasarı üzerindeki in vitro etkisine bakılmıştır. Lösin ve aKIC, deney grubunda kontrol grubundan önemli ölçüde daha yüksek bir DNA hasar indeksi ile sonuçlanmıştır ve L-Kar, bu hasarı, özellikle aKIC nedeniyle önemli ölçüde önleyebildiği bulunmuştur (Mescka ve ark., 2014).

Pediatrik yoğun bakım bölümünde olan hastalar üzerindeki yapılan bir çalışmada Lösin seviyeleri 930-4400 $\mu \mathrm{mol} / \mathrm{L}$ arasında olan 4 hastada MSUD tanısı konulmuştur. Hızları $4120 \mathrm{ml} / \mathrm{sa} /$ $1.73 \mathrm{~m} 2$ ile $9830 \mathrm{ml} / \mathrm{sa} / 1.73 \mathrm{~m} 2$ arasında olan yüksek akışlı renal replasman tedavisi yöntemi ile başarılı bir şekilde tedavi edilmiştir. Bu çalışmayla renal replasman tedavisinin MSUD'un metabolik krizinde bir tedavi seçeneği olduğu ve akut metabolik dekompansasyonunun tedavisinde başarılı olduğu sonucuna varılmıştır (Aygün ve ark., 2019).

\subsection{Karaciğer Transplantasyonu}

MSUD hastaları, DZAA'lerin nörotoksik metabolitlerinin birikmesinden yakınmaktadırlar. Amino asit bozulmasındaki bu kusur, metabolik krizlere, nörolojik hasara ve hatta ölüme neden olabilir. Standart tedavi, ömür boyu protein kısıtlaması ve disiplin gerektiren bir diyetten oluşur (Fabre ve ark., 2013; Zeltner ve ark., 2014; Herden ve ark., 2019). Raporlar diyete sıkı sıkıya bağlı olan hastalarda bile enfeksiyon veya stres nedeniyle yaşamı tehdit eden krizlerin meydana gelebildiğini söylemektedir (Lee ve ark., 2008). Bu nedenle Karaciğer nakli, MSUD hastaları için hastalık veya diğer katabolik stres varlığında yüksek lösin konsantrasyonları ile ilişkili serebral ödem epizodlarını önlemek için yaygın bir tedavi seçeneği haline gelmiştir (Díaz ve ark., 2014). Bağışlanan bir karaciğer, normal bir diyet için yeterli olan BCKAD aktivitesinin \%9-13'ünü sağlar (Mazariegos ve ark., 2012). BCKAD aktivitesi karaciğerde bulunmakla birlikte kas, kalp, böbrek, beyin ve diğer dokularda da bulunmaktadır. $\mathrm{Bu}$ yüzden, MSUD'li bir hastadan alınan bir karaciğer başka bir hastaya transfer edilebilir (domino karaciğer nakli). MSUD karaciğeri alıcısı valin, izolösin ve lösin metabolize etmek için diğer dokulardan BCKAD kullanır (Khanna ve ark., 2006).

Genel olarak, MSUD'li bireylerde karaciğer transplantasyonunu takiben sonuçlar iyi olmuştur. Yapılan bir çalışmaya göre Karaciğer nakli yapılan MSUD'li 54 hastada genel sağkalım yüzdesi \%98-100 oranında bulunmuştur (Mazariegos ve ark., 2012). Transplantasyondan sonra hastalar normal diyetleri tolere eder ve plazma DZAA konsantrasyonlarına stabildir (Díaz ve ark., 2014). Diğer bir çalışmaya göre, MSUD hastalarında karaciğer transplantasyonu yapılan çocuklarda endikasyonları, klinik ve nörolojik durumu değerlendirmek amacıyla 1991-2010 yılları arasında MSUD için 8 karaciğer nakilli hasta incelenmiştir. Transplantasyon sonrası ortalama takip süresi 12,2 yıl idi. Ayrıca transplantasyondan sonra, hastalardan hiçbirinin son 3 yil içinde hastaneye yatmadığ dekompansasyon olmadığını bulmuşlardır. 5'i normal okul eğitimini izledi, 2'sinde motor engelli, 2'sinde konvülsif nöbet vardı. Ortalama lösin seviyeleri, hemen nakil sonrası dönemde $<350 \mu \mathrm{mol} / \mathrm{L}$ idi, maksimum alloizolösin seviyesi ise ortalama $20 \mu \mathrm{mol} / \mathrm{L}$ idi. Bu çalışma ile karaciğer naklinin beyin hasarını durduran klasik MSUD için etkili bir tedavi olduğuna varılmıştır (Díaz ve ark., 2014). 


\section{Sonuç}

Otozomal resesif geçişli kalıtsal bir hastalık olan Akçaağaç şurubu idrar kokusu hastalığı BCKAD enziminin aktivitesindeki bozukluk sonucu oluşmaktadır. MSUD hastalığına sahip çocuklar tanı konduğu andan itibaren ömür boyu beslenme tedavisine uyum sağlamaları gerekir.

Çalışmanın sonucuna göre ömür boyu uygulanan beslenme tedavisinde valin, lösin, izolösin dallı zincirli amino asitlerinin nörolojik gelişim açısından kısıtlanması gerektiği ancak endojen olarak sentezlenemediğinden aşırı kısıtlanmasının da zayıf büyüme gibi komplikasyonları geliştirebildiği gözlemlenmiştir. $\mathrm{Bu}$ sonuçlara göre dallı zincirli amino asitlerin hedeflenen referans aralıkları içerisinde verilmesi gerekmektedir.

Ayrıca MSUD hastalarının katobolik sürece girmemeleri için enerji gereksinimleri RDA'nın üzerinde ve en az 120-150 kcal/kg olması gerekir. Enerji gereksiniminin karşılanmaması ile beraber protein, vitamin, mineral açısından eksik kalınması sonucunda çocuklarda deri lezyonları, sık enfeksiyonlar, büyüme ve gelişme geriliği görülür.

MSUD'li bireylerin günlük protein gereksinmesi DZAA içermeyen özel aminoasit karışımları ve doğal besinler ile sağlanmalıdır. Doğal protein kaynaklarından sağlanan DZAA'ler özellikle tahıl ürünleri, meyveler ve sebzelerden alınmalıdır. Bu derlemede, MSUD'li hastalarda uygulanan beslenme tedavisinin güncel yaklaşımları ele alınarak, erken teşhis ve doğru beslenme tedavisiyle çocuklarda zihinsel hasarın önlenmesi ve büyüme, gelişme geriliği gibi diğer hayati hastalıkların önüne geçilmesinin üzerinde durulmuştur. Protein metabolizma hastalığ 1 olan MSUD üzerine yapılmış çalışmalar kısıtlıdır ve bu derleme okuyuculara bir yol gösterici olabilmek üzere sunulmuştur.

\section{Kaynakça}

[1] Abi-Wardé, M. T., Roda, C., Arnoux, J. B., Servais, A., Habarou, F., Brassier, A., Pontoizeau, C., Barbier, V., Bayart, M., Leboeuf, V., Chadefaux-Vekemans, B., Dubois, S., Assoun, M., Belloche, C., Alili, J. M., Husson, M. C., Lesage, F., Dupic, L., Theuil, B., Ottolenghi, C., ... de Lonlay, P. (2017). Long-term metabolic follow-up and clinical outcome of 35 patients with maple syrup urine disease. Journal of inherited metabolic disease, 40(6), 783-792. https://doi.org/10.1007/s10545-017-0083-x

[2] Aktuğlu Zeybek Ç. (2004). Doğumsal Metabolik Hastalıklarda Beslenme. Sağlıkta ve Hastalıkta Beslenme Sempozyum Dizisi No: 41 - Kasim 2004; s.217-232.

[3] Altuntaş, V, Gök, M. (2020). Protein - Protein Etkileşimi Tespit Yöntemleri, Veri Tabanları ve Veri Güvenilirliği. Avrupa Bilim ve Teknoloji Dergisi, (19), 722-733 . DOI: 10.31590/ejosat. 724390

[4] Aygün, F., Kıykım, E., Aktuğlu-Zeybek, Ç., Zubarioğlu, T., \& Cam, H. (2019). Treatment of maple syrup urine disease with high flow hemodialysis in a neonate. The Turkish journal of pediatrics, 61(1),

107-110. https://doi.org/10.24953/turkjped.2019.01.017

[5] Blackburn, P. R., Gass, J. M., Vairo, F., Farnham, K. M., Atwal, H. K., Macklin, S., Klee, E. W., \& Atwal, P. S. (2017). Maple syrup urine disease: mechanisms and management. The application of clinical genetics, 10, 57-66. https://doi.org/10.2147/TACG.S125962
[6] Carecchio, M., Schneider, S. A., Chan, H., Lachmann, R., Lee, P. J., Murphy, E., \& Bhatia, K. P. (2011). Movement disorders in adult surviving patients with maple syrup urine disease. Movement disorders : official journal of the Movement Disorder Society, 26(7), 1324-1328. https://doi.org/10.1002/mds.23629

[7] Calcar S.V (2015). Nutrition Management of Maple Syrup Urine Disease. Nutrition Management of Inherited Metabolic Diseases, 173-183. doi:10.1007/978-3-319-14621-8_16

[8] Chapman KA. (2014) Systemic organic acidemias: Identification, diagnosis, management and long term complications. J Pediatr Biochem. 2014;4(4):193-200.

[9] Demir M. K, Canda E, Kağnıcı M, Atik Y. A, Kalkan S. U, Habif S, Onay H, Çoker M (2016). Dallı Zincirli Aminoasidopati Sonucu Gelişen Organik Asidemiler: Ege Tip Deneyimi. The Journal of Pediatric Research, 3(2), 76 81.

[10] Díaz, V. M., Camarena, C., de la Vega, Á., Martínez-Pardo, M., Díaz, C., López, M., Hernández, F., Andrés, A., \& Jara, P. (2014). Liver transplantation for classical maple syrup urine disease: long-term follow-up. Journal of pediatric gastroenterology and nutrition, 59(5), 636-639. https://doi.org/10.1097/MPG.0000000000000469

[11] Fabre, A., Baumstarck, K., Cano, A., Loundou, A., Berbis, J., Chabrol, B., \& Auquier, P. (2013). Assessment of quality of life of the children and parents affected by inborn errors of metabolism with restricted diet: preliminary results of a cross-sectional study. Health and quality of life outcomes, 11, 158. https://doi.org/10.1186/1477-7525-11-158

[12] Frazier, D. M., Allgeier, C., Homer, C., Marriage, B. J., Ogata, B., Rohr, F., Splett, P. L., Stembridge, A., \& Singh, R. H. (2014). Nutrition management guideline for maple syrup urine disease: an evidence- and consensus-based approach. Molecular genetics and metabolism, 112(3), 210 217. https://doi.org/10.1016/j.ymgme.2014.05.006

[13] Goedde, H. W., Langenbeck, U., Brackertz, D., Keller, W., Rokkones, T., Halvorsen, S., Kiil, R., \& Merton, B. (1970). Clinical and biochemical-genetic aspects of intermittent branched-chain ketoaciduria. Report of two Scandinavian families. Acta paediatrica Scandinavica, 59(1), 83-87. https://doi.org/10.1111/j.1651-2227.1970.tb15519.x

[14] Herden, U., Grabhorn, E., Santer, R., Li, J., Nadalin, S., Rogiers, X., Scherer, M. N., Braun, F., Beime, J., Lenhartz, H., Muntau, A. C., \& Fischer, L. (2019). Surgical Aspects of Liver Transplantation and Domino Liver Transplantation in Maple Syrup Urine Disease: Analysis of 15 Donor-Recipient Pairs. Liver transplantation : official publication of the American Association for the Study of Liver Diseases and the International Liver Transplantation Society, 25(6), 889-900. https://doi.org/10.1002/lt.25423

[15] Hoffmann, B., Helbling, C., Schadewaldt, P., \& Wendel, U. (2006). Impact of longitudinal plasma leucine levels on the intellectual outcome in patients with classic MSUD. Pediatric research, 59(1), 17-20. https://doi.org/10.1203/01.pdr.0000190571.60385.34

[16] Kale, Y , Karaoğlu, E . (2017). Kraniyal görüntüleme bulguları ile akçaağaç şurubu idrar hastalığı . Ege Tıp Dergisi , 56 (2) , 99-101 . DOI: 10.19161/etd.344253

[17] Kara A. (2012) Pediatrik Metabolizma Hastalıkları ve Beslenme Polikliniğinde Tanı Alan veya Takibe Giren Kalıtsal Metabolik Hastalığı Olan Hastaların Tanılarının, Klinik ve Laboratuar Bulgularının Analizi ile Takip Sonuçlarının Değerlendirilmesi Uzmanlık Tezi- Adana. 
[18] Karahan, M. A., Sert, H., Havlioğlu, İ., \& Yüce, H. H. (2014). The Anaesthetic Management of a Patient with Maple Syrup Urine Disease. Turkish journal of anaesthesiology and reanimation, $42(6)$,

$355-357$. https://doi.org/10.5152/TJAR.2014.07830

[19] Kathait, A. S., Puac, P., \& Castillo, M. (2018). Imaging Findings in Maple Syrup Urine Disease: A Case Report. Journal of pediatric neurosciences, 13(1), 103-105. https://doi.org/10.4103/JPN.JPN_38_17

[20] Khanna, A., Hart, M., Nyhan, W. L., Hassanein, T., PanyardDavis, J., \& Barshop, B. A. (2006). Domino liver transplantation in maple syrup urine disease. Liver transplantation : official publication of the American Association for the Study of Liver Diseases and the International Liver Transplantation Society, 12(5), 876-882. https://doi.org/10.1002/lt.20744

[21] Koç, İ., \& Eryurt, M. A. (2017). The Causal Relationship Between Consanguineous Marrıages And Infant Mortality In Turkey. Journal of Biosocial Science,49(4), 536-555. https://doi.org/10.1017/S002193201600033X

[22] Köksal G, Gökmen H. (2019) Çocuk Hastalıklarında Beslenme Tedavisi. Hatipoğlu Yayınları:124. Sertifika No:13777. Sayfa numaras1: 446-450.

[23] Köksal G, Gökmen Özel H. (2008) Metabolik Hastalıklarda Beslenme. Sağlık Bakanlığı Yayın No: 728. ISBN : 978-975590-244-9. 2008-ANKARA.

[24] Köseoğlu, S . (2019). Bazı Tahıl Ürünlerinin Protein Kalite İndeksinin Protein Sindirilebilirliği - Düzeltilmiş Amino Asit Skoru (PDCAAS) Metodu ile Belirlenmesi. . Avrupa Bilim ve Teknoloji Dergisi , (17) , 477-482 . DOI: 10.31590/ejosat.633638

[25] Köseoğlu, S . (2020). Besin İntoleransı ve Tanı Testleri . Avrupa Bilim ve Teknoloji Dergisi , (18) , 616-620 . DOI: 10.31590/ejosat.679424

[26] Lee, J. Y., Chiong, M. A., Estrada, S. C., Cutiongco-De la Paz, E. M., Silao, C. L., \& Padilla, C. D. (2008). Maple syrup urine disease (MSUD)--clinical profile of 47 Filipino patients. Journal of inherited metabolic disease, 31 Suppl 2, S281-S285. https://doi.org/10.1007/s10545-008-0859-0

[27] Mazariegos, G. V., Morton, D. H., Sindhi, R., Soltys, K., Nayyar, N., Bond, G., Shellmer, D., Shneider, B., Vockley, J., \& Strauss, K. A. (2012). Liver transplantation for classical maple syrup urine disease: long-term follow-up in 37 patients and comparative United Network for Organ Sharing experience. The Journal of pediatrics, 160(1), 116-21.e1. https://doi.org/10.1016/j.jpeds.2011.06.033

[28] Mescka, C. P., Wayhs, C. A., Guerreiro, G., Manfredini, V., Dutra-Filho, C. S., \& Vargas, C. R. (2014). Prevention of DNA damage by L-carnitine induced by metabolites accumulated in maple syrup urine disease in human peripheral leukocytes in vitro. Gene, 548(2), 294-298. https://doi.org/10.1016/j.gene.2014.07.051

[29] Muelly, E. R., Moore, G. J., Bunce, S. C., Mack, J., Bigler, D. C., Morton, D. H., \& Strauss, K. A. (2013). Biochemical correlates of neuropsychiatric illness in maple syrup urine disease. The Journal of clinical investigation, 123(4), 18091820. https://doi.org/10.1172/JCI67217

[30] Malbon K. (2006). Atlas of metabolic diseases, 2nd edition. Archives of Disease in Childhood, 91(2), 203. https://doi.org/10.1136/adc.2005.087619

[31] Samour PQ, King K. (2016) Pediatrik Beslenmenin Esasları. Essentials of Pediatric Nutrition. Yayın no:1585. Sayfa Numaras1:123-132.
[32] Scaini, G., Jeremias, I. C., Morais, M. O., Borges, G. D., Munhoz, B. P., Leffa, D. D., Andrade, V. M., Schuck, P. F., Ferreira, G. C., \& Streck, E. L. (2012). DNA damage in an animal model of maple syrup urine disease. Molecular genetics and metabolism, 106(2), 169-174. https://doi.org/10.1016/j.ymgme.2012.04.009

[33] Scott, A. I., Cusmano-Ozog, K., Enns, G. M., \& Cowan, T. M. (2017). Correction of hyperleucinemia in MSUD patients on leucine-free dietary therapy. Molecular genetics and metabolism, 122(4),

$156-159$. https://doi.org/10.1016/j.ymgme.2017.09.012

[34] Scriver, C. R., Mackenzie, S., Clow, C. L., \& Delvin, E. (1971). Thiamine-responsive maple-syrup-urine disease. Lancet (London, England), 1(7694), 310-312. https://doi.org/10.1016/s0140-6736(71)91041-5

[35] Strauss, K. A., \& Morton, D. H. (2003). Branched-chain Ketoacyl Dehydrogenase Deficiency: Maple Syrup Disease. Current treatment options in neurology, 5(4), 329 341. https://doi.org/10.1007/s11940-003-0039-3

[36] Strauss, K. A., Carson, V. J., Soltys, K., Young, M. E., Bowser, L. E., Puffenberger, E. G., Brigatti, K. W., Williams, K. B., Robinson, D. L., Hendrickson, C., Beiler, K., Taylor, C. M., Haas-Givler, B., Chopko, S., Hailey, J., Muelly, E. R., Shellmer, D. A., Radcliff, Z., Rodrigues, A., Loeven, K., ... Morton, D. H. (2020). Branched-chain $\alpha$-ketoacid dehydrogenase deficiency (maple syrup urine disease): Treatment, biomarkers, and outcomes. Molecular genetics and metabolism, 129(3), 193-206. https://doi.org/10.1016/j.ymgme.2020.01.006

[37] Strauss, K. A., Puffenberger, E. G., \& Carson, V. J. (2006). Maple Syrup Urine Disease. In M. P. Adam (Eds.) et. al., GeneReviews ${ }^{\circledR}$. University of Washington, Seattle.

[38] Strauss, K. A., Wardley, B., Robinson, D., Hendrickson, C., Rider, N. L., Puffenberger, E. G., Shellmer, D., Moser, A. B., \& Morton, D. H. (2010). Classical maple syrup urine disease and brain development: principles of management and formula design. Molecular genetics and metabolism, 99(4), 333-345. https://doi.org/10.1016/j.ymgme.2009.12.007

[39] Tanacan, A., Gurbuz, B. B., Aydin, E., Erden, M., Coskun, T., \& Beksac, M. S. (2019). Prenatal Diagnosis of Organic Acidemias at a Tertiary Center. Balkan journal of medical genetics : BJMG, 22(1), 29-34. https://doi.org/10.2478/bjmg-2019-0003

[40] Zeltner, N. A., Huemer, M., Baumgartner, M. R., \& Landolt, M. A. (2014). Quality of life, psychological adjustment, and adaptive functioning of patients with intoxication-type inborn errors of metabolism - a systematic review. Orphanet journal of rare diseases, 9, 159. https://doi.org/10.1186/s13023-0140159-8 